\title{
Cloud Computing Pricing Models: A Survey
}

\author{
May Al-Roomi, Shaikha Al-Ebrahim, Sabika Buqrais and Imtiaz Ahmad \\ Department of Computer Engineering, College of Engineering and Petroleum, \\ Kuwait University, Kuwait \\ Eng.may87@gmail.com,shaikha_alebrahim@hotmail.com, \\ eng_sabika80@yahoo.com,imtiaz@eng.kuniv.edu.kw
}

\begin{abstract}
Cloud computing is emerging as a promising field offering a variety of computing services to end users. These services are offered at different prices using various pricing schemes and techniques. End users will favor the service provider offering the best QoS with the lowest price. Therefore, applying a fair pricing model will attract more customers and achieve higher revenues for service providers. This work focuses on comparing many employed and proposed pricing models techniques and highlights the pros and cons of each. The comparison is based on many aspects such as fairness, pricing approach, and utilization period. Such an approach provides a solid ground for designing better models in the future. We have found that most approaches are theoretical and not implemented in the real market, although their simulation results are very promising. Moreover, most of these approaches are biased toward the service provider.
\end{abstract}

Keywords: Cloud computing; pricing models; charging models; survey; fairness

\section{Introduction}

Cloud computing is emerging as a vital practice for the online provisioning of computing resources as services. This technology allows scalable on-demand sharing of resources and costs among a large number of end users. It enables end users to process, manage, and store data efficiently at very high speeds at reasonable prices. Customers of cloud computing do not need to install any kind of software and can access their data worldwide from any computer as long as an Internet connection is available.

Many definitions have been presented for cloud computing [1, 2, 3]. Foster et al., [1] defined cloud computing as "a large-scale distributed computing paradigm that is driven by economies of scale, in which a pool of abstracted, virtualized, dynamically-scalable, managed computing power, storage, platforms, and services are delivered on demand to external customers over the Internet." Cloud computing provides various computing services online based on SLAs between the provider and the consumer.

Cloud computing providers offer many services to their customers [29], including infrastructure as a service (IaaS), platform as a service (PaaS), software as a service (SaaS), storage as a service (STaaS), security as a service (SECaaS), test environment as a service (TEaaS), and many more. A cloud computing provider's typical goal is to maximize its revenues with its employed pricing scheme, while its customers' main goal is to obtain the highest level of quality of service (QoS) feasible for a reasonable price. Therefore, satisfying both parties requires an optimal pricing methodology. The price charged is one of the most important metrics that a service provider can control to encourage the usage of its services. 
Pricing is a critical factor for organizations offering services or products [30]. How the price is set affects customer behavior, loyalty to a provider, and the organization's success. Therefore, developing an appropriate pricing model will help achieve higher revenues. The price determined for a service or product must consider the manufacturing and maintenance costs, market competition, and how the customer values the service or product offered. Iveroth et al., [31] analyzed the possible sets of price models that different organizations can employ. Their research illustrated how price is connected to a set of many implicit features of the price model. Such an approach helps in resolving many issues regarding pricing between the customer and the provider.

Software vendors utilize many pricing techniques. For example, a typical pricing approach is to pay once for limitless usage. However, this approach is rigid and does not consider many other factors that affect pricing, such as the age of resources and price fairness [4]. Many major cloud computing providers (e.g., Amazon Web Services [5] and Google App Engine [6]) employ "pay-per-use fixed pricing," which charges users according to their overall resource consumption. "Pay for resources" is another technique, in which users are charged according to the storage or bandwidth size provided. Subscription is another pricing technique, in which the customer subscribes with a certain service provider for a fixed price per unit for long periods of time. Moreover, a service level agreement (SLA) is an essential part of cloud computing. It describes the negotiations between the provider and the customer regarding the services provided. The final agreement is verified via a contract between the involved parties. An SLA might involve agreements regarding QoS, pricing, guarantees, and so on.

Samimi and Patel [25] introduced a review and comparison of the recent pricing models in grid and cloud computing and their economic models. They also highlighted the differences in grid and cloud computing by comparing their usage, standardization, virtualization, and SLAs. They studied pricing models thoroughly in grid computing and compared them to those in cloud computing. However, the number of pricing models compared is insufficient to draw conclusions. Moreover, the fairness of each model, which is an important factor to assess pricing models, was not stated.

In our work, we present a thorough comparison between many proposed cloud computing pricing models and schemes. We consider many factors that affect pricing and user satisfaction, such as fairness, QoS, and more, by highlighting their importance in recent markets. We consider recent pricing models and their pricing approaches. We also introduce the pros and cons of each model to provide a solid ground to design future improved models.

The rest of the paper is organized as follows. Section II presents background information for cloud computing and pricing. Section III describes important aspects of cloud computing. Section IV presents a thorough comparison between various cloud computing price models. Section V includes our conclusions and remarks.

\section{Background}

In this section, we will provide an inclusive background on cloud computing key concepts and pricing generally and within the cloud.

\subsection{Cloud computing service models}

Cloud computing is emerging as one of the most promising technologies. Its providers supply many services through service models to their customers. Infrastructure as a service (IaaS) is among these service models: computers are offered as physical or virtual machines to support end users' operations. The service provider is responsible for running and 
maintaining the service. It leases the use of the machines to customers typically on a per-use basis. Therefore, the price represents the amount of resources allocated. Other forms of resources in IaaS include IP addresses, firewalls, load balancers, images in a virtual machine image library, and virtual local area networks (VLANs). Examples of IaaS providers include Google Compute Engine [32], Windows Azure Virtual Machines [26], Amazon CloudFormation [34], Rackspace Cloud [35], and Terremark [36].

Another major type of service model offered by service providers is platform as a service (PaaS). In this type of service, a computing platform is offered to customers. This computing platform includes operating systems, hardware, programming language execution environments, servers, and databases. Developers can benefit immensely from PaaS because they can rent complex hardware and change operating systems dynamically while developing their applications. The drawback is that PaaS lacks some flexibility and may not match the rapidly evolving requirements of some of their customers. Examples of PaaS providers include Amazon Elastic Beanstalk [5], Cloud Foundry [38], Heroku [39], Google App Engine [6], Windows Azure Compute [41], and Force.com [42].

Software as a service (SaaS) is another type of service model offered to customers. In this model, software applications are installed in the cloud and operated by service provides, and end users can access the software from cloud clients. The service provider is responsible for maintaining the software. SaaS has many advantages, such as easier administration, elasticity, worldwide accessibility, and compatibility. End users are typically charged a flat fee monthly or yearly. Examples of SaaS include Google Apps [43], Microsoft Office 365 [44], Innkeypos [45], Quickbooks Online [46], and Limelight Video Platform [28].

Many other types of service models are provided. In storage as a service (STaaS), a service provider leases storage to end users by subscription. In security as a service (SECaaS), the security of a service provider is integrated efficiently and cost-effectively in a cooperative infrastructure. Test environment as a service (TEaaS) is another service provided to users, in which on-demand test environments and their data are given to customers. Figure 1 illustrates the basic types of service models in cloud computing.

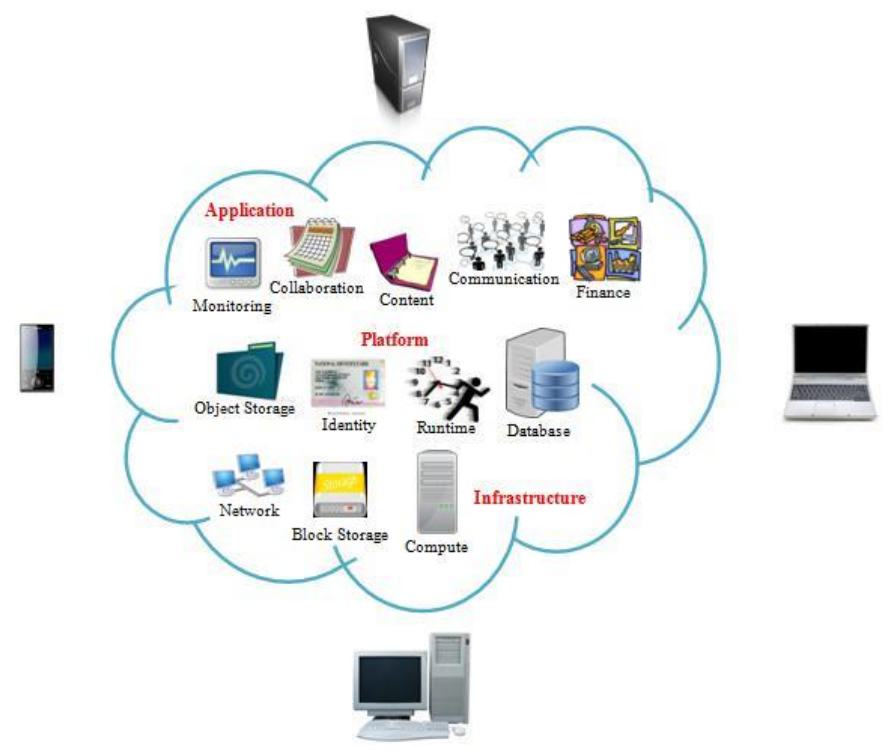

Figure 1. The basic types of service models in cloud computing 


\subsection{Cloud computing characteristics and attributes}

Cloud computing offers their end users numerous gains. Mell and Grance [7] described the essential characteristics of cloud computing, including on-demand self-service, broad network access, resource pooling, rapid elasticity, and measured service. Iyer and Henderson [8] described the seven major capabilities of cloud computing that can be utilized to develop new cloud-based strategies to respond to emerging challenges: controlled interface, location independence, sourcing independence, ubiquitous access, virtual business environment, addressability, traceability, and rapid elasticity.

\subsection{Cloud computing deployment models}

Cloud computing services can be categorized into different deployment models [7, 18, 19] depending on the dedicated audience, service limits, or clouding approach. Four main deployment models are introduced: the public cloud, private cloud, hybrid cloud, and community cloud. In the public cloud model, the cloud resources and services are made available to the general public over the Internet. These services can be free or charged per use. In the private model, the cloud computing environment is made available exclusively to a certain organization. In the hybrid cloud, the service provider is in charge of external computing resources in addition to the internal resources. It can be viewed as composed of a public cloud and a private one. In a community cloud, the cloud computing environment is shared by multiple organizations from a certain community with similar objectives.

\subsection{Pricing in the cloud}

Pricing is the process of determining what a service provider will receive from an end user in exchange for their services. Weinhardt et al., [9] claimed that cloud computing success in the IT market can be obtained only by developing adequate pricing techniques. The pricing process can be as follows: fixed, in which the customer is charged the same amount all the time; dynamic, in which the price charged changes dynamically; or market-dependent, in which the customer is charged based on the real-time market conditions [17]. Fixed pricing mechanisms include the pay-per-use model, in which the customers pay for the amount they consume of a product or the amount of time they use a certain service. Subscription is another type of fixed pricing, in which the customer pays a fixed amount of money to use the service for longer periods at any convenient time or amount. A list price is another form of fixed pricing, in which a fixed price is found in a catalog or a list. On the other hand, differential or dynamic pricing implies that the price changes dynamically according to the service features, customer characteristics, amount of purchased volumes, or customer preferences. Marketdependent pricing, however, depends on the real-time market conditions such as bargaining, auctioning, demand behavior, and yield management. The following are the most pertinent factors that influence pricing in cloud computing [10]:

1. Initial costs. This is the amount of money that the service provider spends annually to buy resources.

2. Lease period. This is the period in which the customer will lease resources from the service provider. Service providers usually offer lower unit prices for longer subscription periods.

3. QoS. This is the set of technologies and techniques offered by the service provider to enhance the user experience in the cloud, such as data privacy and resource availability. The better QoS offered, the higher the price will be. 
4. Age of resources. This is the age of the resources employed by the service provider. The older the resources are, the lower the price charged will be. This is because resources can sustain wear over time, which reduces their financial value.

5. Cost of maintenance. This is the amount of money that the service provider spends on maintaining and securing the cloud annually.

After determining the prices based on the aforementioned factors, the service provider must consider other questions. Is the price fair? What about the other service providers? Do they offer better services for lower prices? Is the service demanded by customers at the same rate?

Although it is not trivial to articulate what is fair, fairness can be defined as a judgment as to whether the outcome of a process is reasonable or just [11]. Therefore, judging price fairness implies comparing it to relevant references and standards. Price comparisons can be either explicit or implicit [12]. Explicit price comparison means that the price is compared to another price or a range of prices. For example, saying, "I paid more than another customer" is an explicit price comparison with another price. On the other hand, saying, "I paid more than I used to" is an example of an explicit price comparison to a range of prices. These price comparisons lead to one of three types of judgments by customers: equality, advantaged inequality, or disadvantaged inequality [12]. Equality does not necessarily imply fairness but could lead to it. On the other hand, inequality implies that the price is less fair than it should be or that it is unfair. In advantaged inequality, the customer will perceive the price to be unfair, but this is due to the customer's own interest in maximizing his or her outcome by trying to purchase at a lower price compared to other customers. In this case, the price will trigger less negative emotions (e.g., anger, outrage, and so on). However, in disadvantaged inequality, the price is perceived to be more unfair than that of the advantaged inequality and will trigger more negative emotions.

Merriam-Webster defines competition in economics as "the effort of two or more parties acting independently to secure the business of a third party by offering the most favorable terms." Market competition between service providers will not allow them to set the prices as high as they wish. Customers will search for the service provider that offers the highest level of QoS with the lowest price. Instead, service providers can adopt new technologies and techniques that will help them lower their costs and, hence, their prices.

The main influences on pricing are supply and demand. Demand refers to the level at which a service or good is desired by customers. The law of demand states that, when the price of a good or service is higher, fewer customers will demand that good or service. Supply, on the other hand, reflects the amount of goods or services that the market can produce for a certain price. Therefore, price is considered a reflection of supply and demand.

\section{Aspects of cloud computing pricing models}

A customer will evaluate a prospective service provider based on three main parameters: pricing approach, QoS, and utilization period. The pricing approach describes the process by which the price is determined. The pricing approach could be one of the following [31]: fixed priced regardless of volume, fixed price plus per-unit rate, assured purchase volume plus perunit price rate, per-unit rate with a ceiling, and per-unit price. The fixed price regardless of volume charges the customer a fixed price regardless of the volume of the service or product utilized. The fixed price plus per-unit charges the customer a fixed price plus a unit rate. In the assured purchase volume plus per-unit price rate, the customer pays a fixed price for a certain quantity. If the customer's utilization exceeds that quantity, the customer has to pay a 
fixed rate per unit for the extra utilization. In the per-unit rate with a ceiling approach, the customer pays the per-unit rate up to a certain limit. The provider will not charge the customer above that limit. In the price per unit approach, the customer is charged a different price per unit.

The quality of service describes the requirements for what a service provider should provide to his customers. QoS requirements include the availability of service, security, privacy, scalability, and integrity of the service provider. If the service provider ensures that these requirements are maintained at a high level, the quality of the service offered will increase. This will increase the number of customers and loyalty to the service provider.

The utilization period can be defined as the period in which the customer has the right to utilize the provider services based on SLAs between the two parties. It could be perpetual, based on the subscription period, or a pay-per-use model. Figure 2 below describes the main aspects of pricing models.

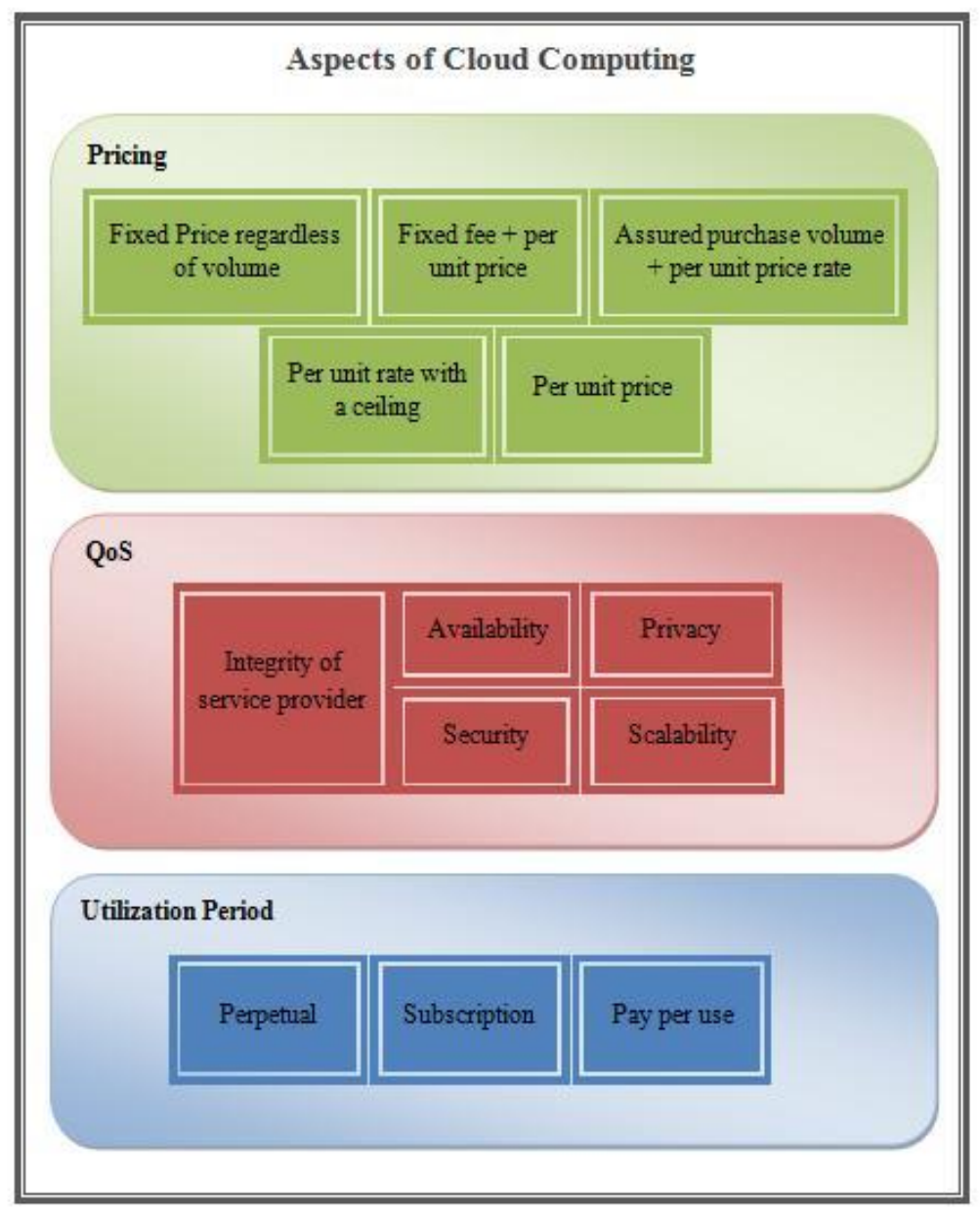

Figure 2. Aspects of Cloud Computing

\section{Cloud Computing Pricing Models}

Different service providers employ different schemes and models for pricing. However, the most common model employed in cloud computing is the "pay-as-you go" model. Customers 
pay a fixed price per unit of use. Amazon [5], considered the market leader in cloud computing, utilizes such a model by charging a fixed price for each hour of virtual machine usage. The "pay-as-you-go" model is also implemented by other leading enterprises such as Google App Engine [6] and Windows Azure [26]. Another common scheme employed by these leading enterprises is the "pay for resources" model. A customer pays for the amount of bandwidth or storage utilized. Subscription, where a customer pays in advance for the services he is going to receive for a pre-defined period of time, is also common.

Nevertheless, many useful theoretical studies for cloud computing pricing have been introduced. Sharma et al., [10] proposed a novel financial economic model capable of providing a high level of QoS to customers. They employed the financial option theory and treated the cloud resources as assets to capture their realistic value. The price determined using this model represented the optimal price that the service provider should charge its customers to recover the initial costs. The financial option theory gave a lower boundary on the price that should be charged to customers. The upper boundary of the price was determined using a proposed compounded Moore's law. This law, presented by the authors, combined Moore's law [15] with the compounded interest formula. The authors claimed that, if the price was set between these two boundaries, it would be beneficial for both customers and service providers. This approach was interesting; however, it did not take into consideration the maintenance costs. The authors also assumed that the initial costs would be the same for clients and providers, which is not true. Service providers get discounts for buying a larger amount of assets.

Wang et al., [14] proposed an algorithmic solution to optimize data center net profit with deadline-dependent scheduling by jointly maximizing revenues and minimizing electricity costs. They developed two distributed algorithms for the net profit optimization: Net Profit Optimization for Divisible jobs (NPOD), and Net Profit Optimization for Indivisible Jobs (NPOI). An indivisible job is a job that cannot be interrupted, while a divisible job can be interrupted or divided. The authors proved via simulations their algorithm's capabilities to increase revenues and reduce electricity costs by comparing it to the Largest Job First (LJF) algorithm. However, the authors considered only static job arrivals and departures. They also assumed that the servers at all data centers were homogenous, which is not realistic.

Macias and Guitart [16] proposed a genetic model for pricing in cloud computing markets. Choosing a good pricing model via their genetic algorithms involved three main steps: define a chromosome, evaluate it, and finally select the best pairs of chromosomes for reproduction and discarding those with the worst results. The results of the simulation illustrated that genetic pricing acquired the highest revenues in most of the scenarios. Service providers employing genetic pricing achieved revenues up to $100 \%$ greater than the other dynamic pricing strategies and up to $1000 \%$ greater than the fixed pricing strategy. The proposed genetic model with a flexible genome was proven to be more stable against noise and earned more money than the one with the rigid genome. The proposed genetic model is easy to implement, flexible, and easily adapted to a set of various parameters that influence pricing. The genetic pricing approach can be further explored by defining relations between the parameters that influence pricing.

Mihailescu and Teo [20] introduced a dynamic pricing scheme for federated clouds, in which resources are shared among many cloud service providers. Federated clouds are implemented to improve reliability and scalability for both users and providers. Users in the federated environment were assumed to be capable of both buying and selling resources. In the case of high market demand, fixed pricing would minimize seller welfare because he would not be capable of raising his price. Similarly, when demand was low, user utility would be minimized because he would be charged more than the market price. Therefore, dynamic 
pricing would be beneficial in such environments because it would set the price according to the levels of supply and demand. It would also allow the offering of many types of resources to end users. The authors carried out simulations to determine the efficiency of this approach by comparing it to a fixed pricing scheme. They found that dynamic pricing achieved better average performance with increasing buyer welfare and numbers of successful requests up to $200 \%$. However, fixed pricing achieved better scalability in the case of high demand in the market.

Yeoa et al., [21] described the difference between fixed and variable prices. Fixed prices were easier to understand and more straightforward for users. However, fixed pricing could not be fair to all users because not all users had the same needs. Their study proposed charging variable prices with advanced reservation. Charging variable pricing with advanced reservation would let users know the exact expenses that are computed at the time of reservation even though they were based on variable prices. The paper emphasized the importance of implementing autonomic metered pricing to increase revenues. Autonomic metered pricing can also be straightforward for users through the use of advanced reservations. The advantage of advanced reservations is that users can not only know the prices of their required resources in the future but are also able to guarantee access to future resources to better plan and manage their operations.

Rohitratana and Altmann [22] analyzed four dynamic pricing schemes: derivative-follower (DF), demand-driven (DD), penetration (PN), and skimming (SK). They developed an agentbased simulation of a software market that allowed the trading of two types of software licensing models. The two types of software licensing models were SaaS and perpetual software (PS). Rohitratana and Altmann's [22] simulation results indicated that the DD pricing scheme was the best scheme in ideal cases. However, in the real world, obtaining perfect information about customers and competitors is almost impossible. This makes the DD pricing scheme difficult to implement. PN and SK pricing schemes can be implemented easily, while they give results close to the DD pricing scheme.

Nähring [23] focused his study on four basic pricing strategies. The basic pricing strategies were cost-based pricing, customer-based pricing, competition-based pricing, and value-based pricing. Nähring [23] highlighted the pros of cons of each one of the pricing strategies. On the other hand, Jäätmaa [24] emphasized strongly that a "pay-per-use" pricing mechanism was regarded as the key characteristic of cloud computing pricing. The study found that pay-peruse pricing significantly changed the risk-sharing model between the service provider and the customer as the customer's commitment decreased. In addition, a pay-per-use mechanism could decrease the service provider's incoming cash flow. Jäätmaa, therefore, proposed a new form of generic cloud computing pricing [24] that balanced the balanced the commitment between the service provider and the customer.

Li et al., [27] proposed a pricing algorithm for cloud computing resources. This proposal used the cloud bank agent model as a resource agency because it could provide the proper analysis and assistance for all members. The authors used a price update iterative algorithm to determine the price. It analyzed the historical utilization ratio of the resources, iterated current prices constantly, assessed the availability of resources for the next round, and determined the final price. The model included a user request broker (GCA), cloud banking, a cloud service agent (CSA), and a cloud resource agent (GRA). The proposed pricing model was comparatively fixed because it could not adapt to the rapid changes that typically occur in the market. However, it could reduce the costs to providers and maximize their revenues, allowing resources to be used more effectively.

Table 1 below compares pricing models inclusively in terms of fairness, implementation, pros, and cons. Pricing models fall into two main types: static and dynamic. In static pricing 
models, the price remains unchanged after it has been determined. In dynamic pricing, the price changes dynamically according to factors such as the resources required, demand, and more.

Table 1. Pricing Model Comparison

\begin{tabular}{|c|c|c|c|c|c|}
\hline $\begin{array}{l}\text { Pricing } \\
\text { Model }\end{array}$ & $\begin{array}{c}\text { Pricing } \\
\text { Approach }\end{array}$ & Fairness & Pros & Cons & Implementation \\
\hline $\begin{array}{c}\text { Pay-as-you- } \\
\text { go model }\end{array}$ & $\begin{array}{l}\text { Price is set by } \\
\text { the service } \\
\text { provider and } \\
\text { remains } \\
\text { constant (static) }\end{array}$ & $\begin{array}{l}\text { Unfair to the } \\
\text { customer } \\
\text { because he } \\
\text { might pay } \\
\text { for more } \\
\text { time than } \\
\text { needed }\end{array}$ & $\begin{array}{l}\text { - Customer } \\
\text { is aware of } \\
\text { the exact } \\
\text { price to be } \\
\text { paid } \\
\text { - Resources } \\
\text { are } \\
\text { reserved } \\
\text { for the } \\
\text { customer } \\
\text { for the paid } \\
\text { period of } \\
\text { time }\end{array}$ & $\begin{array}{l}\text { - Service } \\
\text { provider } \\
\text { might } \\
\text { reserve the } \\
\text { resources } \\
\text { for longer } \\
\text { than the } \\
\text { customer's } \\
\text { utilized } \\
\text { - Service } \\
\text { provider } \\
\text { cannot } \\
\text { raise the } \\
\text { price when } \\
\text { demand is } \\
\text { high; } \\
\text { when } \\
\text { demand is } \\
\text { low, the } \\
\text { user pays } \\
\text { higher } \\
\text { than the } \\
\text { market } \\
\text { price }\end{array}$ & $\begin{array}{c}\text { Commonly } \\
\text { implemented }[5 \text {, } \\
6,26]\end{array}$ \\
\hline Subscription & $\begin{array}{l}\text { Price is based } \\
\text { on the period of } \\
\text { subscription } \\
\text { (static) }\end{array}$ & $\begin{array}{c}\text { Customer } \\
\text { might } \\
\text { sometimes } \\
\text { overpay or } \\
\text { underpay }\end{array}$ & $\begin{array}{l}\text { - Customer } \\
\text { might } \\
\text { underpay } \\
\text { for the } \\
\text { resources } \\
\text { reserved if } \\
\text { he uses } \\
\text { them } \\
\text { extensively }\end{array}$ & $\begin{array}{l}\text { - Customer } \\
\text { might } \\
\text { overpay } \\
\text { for the } \\
\text { resources } \\
\text { reserved if } \\
\text { he does } \\
\text { not use } \\
\text { them } \\
\text { extensivel } \\
\text { y }\end{array}$ & $\begin{array}{c}\text { Commonly } \\
\text { implemented } \\
{[5,6,26]}\end{array}$ \\
\hline $\begin{array}{c}\text { A novel } \\
\text { financial } \\
\text { economic } \\
\text { model [10] }\end{array}$ & $\begin{array}{c}\text { Usage-based } \\
\text { (dynamic) }\end{array}$ & $\begin{array}{c}\text { Fair for both } \\
\text { the service } \\
\text { provider and } \\
\text { the } \\
\text { customer } \\
\text { because the } \\
\text { price is set } \\
\text { between } \\
\text { upper \& } \\
\text { lower } \\
\text { boundaries }\end{array}$ & $\begin{array}{l}\text { Helps the } \\
\text { service } \\
\text { provider } \\
\text { recover its } \\
\text { initial costs } \\
\text { - Provides a } \\
\text { high level } \\
\text { of QoS to } \\
\text { customers }\end{array}$ & $\begin{array}{l}\text { Does not } \\
\text { consider } \\
\text { maintenan } \\
\text { ce costs } \\
\text { and } \\
\text { assumes } \\
\text { the price } \\
\text { charged } \\
\text { for assets } \\
\text { for } \\
\text { customers }\end{array}$ & $\begin{array}{l}\text { Theoretical } \\
\text { approach with } \\
\text { simulations }\end{array}$ \\
\hline
\end{tabular}




\begin{tabular}{|c|c|c|c|c|c|}
\hline $\begin{array}{l}\text { Pay-for- } \\
\text { resources } \\
\text { model }\end{array}$ & $\begin{array}{c}\text { Cost-based } \\
\text { (static) }\end{array}$ & $\begin{array}{l}\text { Fair for both } \\
\text { customers } \\
\text { and the } \\
\text { service } \\
\text { provider }\end{array}$ & $\begin{array}{l}\text { Offers } \\
\text { maximum } \\
\text { utilization } \\
\text { of the } \\
\text { service } \\
\text { provider's } \\
\text { resources }\end{array}$ & $\begin{array}{l}\text { - Hard to } \\
\text { implement }\end{array}$ & $\begin{array}{c}\text { Commonly } \\
\text { implemented } \\
{[5,6,26]}\end{array}$ \\
\hline $\begin{array}{c}\text { Pricing } \\
\text { algorithm } \\
\text { for cloud } \\
\text { computing } \\
\text { Resources } \\
\text { [27] }\end{array}$ & $\begin{array}{l}\text { Real-time } \\
\text { pricing } \\
(\text { dynamic) }\end{array}$ & $\begin{array}{l}\text { Fair for } \\
\text { provider } \\
\text { because it } \\
\text { reduces } \\
\text { costs and } \\
\text { maximizes } \\
\text { revenues }\end{array}$ & $\begin{array}{l}\text { Reduces } \\
\text { the costs of } \\
\text { the } \\
\text { providers; } \\
\text { maximizes } \\
\text { revenues }\end{array}$ & $\begin{array}{l}\text { - Model is } \\
\text { almost } \\
\text { fixed and } \\
\text { cannot } \\
\text { adapt to } \\
\text { rapid } \\
\text { changes } \\
\text { between } \\
\text { supply and } \\
\text { demand in } \\
\text { the market }\end{array}$ & $\begin{array}{l}\text { Theoretical } \\
\text { approach with } \\
\text { simulations }\end{array}$ \\
\hline $\begin{array}{l}\text { Dynamic } \\
\text { resource } \\
\text { pricing on } \\
\text { federated } \\
\text { clouds [20] }\end{array}$ & $\begin{array}{c}\text { Auction-based } \\
\text { pricing } \\
\text { (dynamic) }\end{array}$ & $\begin{array}{l}\text { Fair for both } \\
\text { customers } \\
\text { and the } \\
\text { service } \\
\text { provider } \\
\text { because the } \\
\text { price is set } \\
\text { according to } \\
\text { the level of } \\
\text { supply and } \\
\text { demand }\end{array}$ & 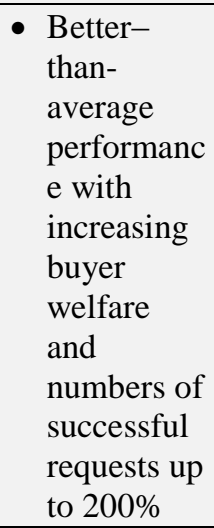 & $\begin{array}{l}\text { - Less } \\
\text { scalability } \\
\text { of high } \\
\text { demand in } \\
\text { the market } \\
\text { than fixed } \\
\text { pricing }\end{array}$ & $\begin{array}{l}\text { Theoretical } \\
\text { approach with } \\
\text { simulations }\end{array}$ \\
\hline $\begin{array}{l}\text { Genetic } \\
\text { model for } \\
\text { pricing in } \\
\text { cloud } \\
\text { computing } \\
\text { markets [16] }\end{array}$ & $\begin{array}{l}\text { Real-time } \\
\text { pricing } \\
\text { (dynamic) }\end{array}$ & $\begin{array}{l}\text { Biased } \\
\text { toward the } \\
\text { service } \\
\text { provider; } \\
\text { the } \\
\text { algorithm } \\
\text { considers } \\
\text { increasing } \\
\text { revenues }\end{array}$ & $\begin{array}{l}\text { - Achieves } \\
\text { very high } \\
\text { revenues } \\
\text { - Stable } \\
\text { against } \\
\text { noises } \\
\text { - Flexible } \\
\text { - Easy to } \\
\text { implement }\end{array}$ & $\begin{array}{l}\text { - Assumes } \\
\text { that the } \\
\text { market } \\
\text { behaves } \\
\text { rationally, } \\
\text { which } \\
\text { might } \\
\text { cause the } \\
\text { model to } \\
\text { underperfo } \\
\text { rm in very } \\
\text { high and } \\
\text { very low } \\
\text { demand } \\
\text { conditions }\end{array}$ & $\begin{array}{l}\text { Theoretical } \\
\text { approach with } \\
\text { simulations }\end{array}$ \\
\hline $\begin{array}{c}\text { Datacenter } \\
\text { net profit } \\
\text { optimization } \\
\text { with } \\
\text { individual } \\
\text { job deadlines } \\
\text { [14] }\end{array}$ & $\begin{array}{c}\text { Based on Job } \\
\text { scheduling } \\
\text { (dynamic) }\end{array}$ & $\begin{array}{c}\text { Biased } \\
\text { toward the } \\
\text { service } \\
\text { provider; it } \\
\text { mainly } \\
\text { reduces } \\
\text { costs and } \\
\text { increases }\end{array}$ & $\begin{array}{l}\text { Maximizes } \\
\text { revenues } \\
\text { for the } \\
\text { service } \\
\text { provider } \\
\text { and } \\
\text { minimizes } \\
\text { electricity }\end{array}$ & $\begin{array}{l}\text { - Considers } \\
\text { only static } \\
\text { job } \\
\text { arrivals } \\
\text { and } \\
\text { departures } \\
\text { and } \\
\text { assumes }\end{array}$ & $\begin{array}{l}\text { Theoretical } \\
\text { approach with } \\
\text { simulations }\end{array}$ \\
\hline
\end{tabular}




\begin{tabular}{|c|c|c|c|c|c|}
\hline & & $\begin{array}{l}\text { revenues for } \\
\text { the provider }\end{array}$ & costs & $\begin{array}{l}\text { that the } \\
\text { servers at } \\
\text { all data } \\
\text { centers are } \\
\text { homogeno } \\
\text { us, which } \\
\text { is not } \\
\text { realistic } \\
\text { - Hard to } \\
\text { implement }\end{array}$ & \\
\hline $\begin{array}{c}\text { Value-based } \\
\text { pricing } \\
{[23]}\end{array}$ & $\begin{array}{l}\text { Prices set } \\
\text { according to the } \\
\text { value perceived } \\
\text { by the customer } \\
\text { (dynamic) }\end{array}$ & $\begin{array}{l}\text { Fair to } \\
\text { producers } \\
\text { where prices } \\
\text { are set on } \\
\text { the value } \\
\text { perceived } \\
\text { by the } \\
\text { customer }\end{array}$ & $\begin{array}{l}\text { - High } \\
\text { revenue on } \\
\text { each item } \\
\text { sold } \\
\text { (advantage } \\
\text { from the } \\
\text { producer's } \\
\text { point of } \\
\text { view). }\end{array}$ & $\begin{array}{l}\text { - Difficult } \\
\text { to obtain } \\
\text { and } \\
\text { interpret } \\
\text { data from } \\
\text { customers, } \\
\text { competitor } \\
\text { s, and } \\
\text { one's own } \\
\text { corporatio } \\
\text { n to } \\
\text { evaluate } \\
\text { customer } \\
\text { perceived } \\
\text { value }\end{array}$ & Implemented \\
\hline $\begin{array}{c}\text { Cost-based } \\
\text { pricing } \\
{[13]}\end{array}$ & $\begin{array}{l}\text { Price set by } \\
\text { adding a profit } \\
\text { element on top } \\
\text { of the cost } \\
\text { (dynamic) }\end{array}$ & $\begin{array}{l}\text { Not fair to } \\
\text { customers } \\
\text { where the } \\
\text { perceived } \\
\text { value of the } \\
\text { product can } \\
\text { be identified } \\
\text { and } \\
\text { apprehended } \\
\text { by the } \\
\text { customer } \\
\text { after the } \\
\text { price is set }\end{array}$ & $\begin{array}{l}\text { - Simplicity } \\
\text { in } \\
\text { calculating } \\
\text { the price }\end{array}$ & $\begin{array}{l}\text { - Tends to } \\
\text { ignore the } \\
\text { role of } \\
\text { consumers }\end{array}$ & Implemented \\
\hline $\begin{array}{c}\text { Competition- } \\
\text { based } \\
\text { pricing } \\
{[33]}\end{array}$ & $\begin{array}{l}\text { Price set } \\
\text { according to } \\
\text { competitors' } \\
\text { prices } \\
\text { (dynamic) }\end{array}$ & $\begin{array}{c}\text { Fair to } \\
\text { customers } \\
\text { where prices } \\
\text { are always } \\
\text { set } \\
\text { according to } \\
\text { competitive } \\
\text { prices } \\
\end{array}$ & $\begin{array}{l}\text { - Easy to } \\
\text { implement }\end{array}$ & $\begin{array}{l}\text { - Does not } \\
\text { take } \\
\text { customers } \\
\text { into } \\
\text { account }\end{array}$ & Implemented \\
\hline $\begin{array}{c}\text { Customer- } \\
\text { based } \\
\text { pricing } \\
{[37]}\end{array}$ & $\begin{array}{l}\text { Price set } \\
\text { according to } \\
\text { what the } \\
\text { customer is } \\
\text { prepared to pay } \\
\text { (dynamic) }\end{array}$ & $\begin{array}{c}\text { Fair to } \\
\text { customers } \\
\text { as } \\
\text { customers } \\
\text { are always } \\
\text { taken into } \\
\text { account }\end{array}$ & $\begin{array}{l}\text { - Takes } \\
\text { customer } \\
\text { perspective } \\
\text { into } \\
\text { account }\end{array}$ & $\begin{array}{l}\text { - Customers } \\
\text { rarely } \\
\text { indicate to } \\
\text { seller what } \\
\text { they are } \\
\text { willing to } \\
\text { pay } \\
\text { - Data are }\end{array}$ & Implemented \\
\hline
\end{tabular}




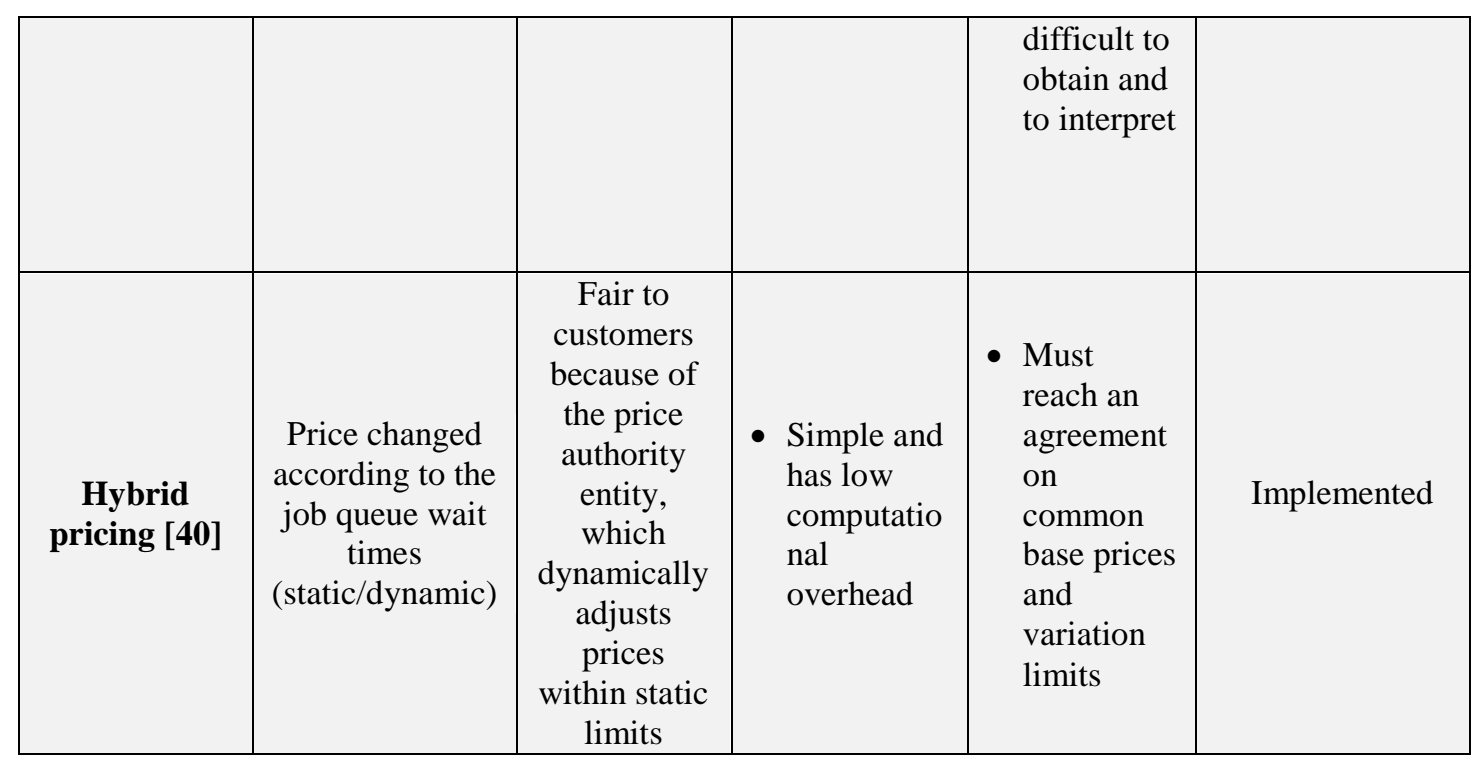

\section{Discussion and Conclusion}

In our work, we have reviewed cloud computing key concepts and attributes and provided a thorough background of pricing in businesses. We have presented inclusive assessments and comparisons between several recent pricing models in cloud computing. We have noted that many efficient pricing models were not implemented in real markets, although their simulation results were promising.

We also noted that most pricing models in cloud computing are biased toward the service provider. Most of them aimed to increase the service provider's revenues and decrease its costs. A better pricing approach would include attributes regarding the end user, such as user satisfaction level, QoS, end user utility, and so on. A customer satisfied with a provider's services will continue to use them in the future and recommend them to peers, which eventually results in higher revenues and popularity among customers.

The customer can choose the service provider with the pricing approach that is most compatible with the customer's behavior. For example, a customer who needs to use the cloud extensively would be better off using the services of a cloud with a static pricing approach than a dynamic one because a static approach would charge less in this case. Customers with limited usage would fare better if they used the services of a cloud with a dynamic pricing approach.

\section{References}

[1] I. Foster, I. Yong, Z. Raicu and S. Lu, "Cloud Computing and Grid Computing 360-Degree Compared", Grid Computing Environments Workshop, (2008).

[2] L. M. Vaquero, L Rodero-Merino, J. Caceres and M. Lindner, "A Break in the Clouds", Towards a Cloud Definition, Comput. Commun. Review, vol. 39, no. 1, (2009).

[3] M. Armbrust, A. Fox, R. Griffith, A. D. Joseph, R. Katz, A. Konwinski, G. Lee, D. Patterson, A. Rabkin, I. Stoica and M. Zaharia, "Above the Clouds: A Berkeley View of Cloud Computing", Publication of Reliable Adaptive Distributed Systems Laboratory, University of California, Berkeley, (2009).

[4] S. Maxwell, "The Price is Wrong: Understanding What Makes a Price Seem Fair and the True Cost of Unfair Pricing", Wiley, (2008).

[5] Amazon Web Services, http://aws.amazon.com/.

[6] Google App Engine, https://appengine.google.com/.

[7] P. Mell and T. Grance, "The NIST Definition of Cloud Computing”, vol. 15, (2009). 
[8] B. Iyer and J. C. Henderson, "Preparing for the Future: Understanding the Seven Capabilities of Cloud Computing", MIS Quart, Executive, vol. 9, no. 2, (2010).

[9] C. Weinhardt, A. Anandasivam, B. Blau, N. Borissov, T. Meini, W. Michalk and J. Stosser, "Cloud Computing - A Classification”, Business Models, and Research Directions, Bus. Models and Inform. Syst. Eng., vol. 1, no. 5, (2009).

[10] B. Sharma, R. K. Thulasiram, P. Thulasiraman, S. K. Garg and R. Buyya, "Pricing Cloud Compute Commodities: A Novel Financial Economic Model", Proc. of IEEE/ACM Int. Symp. on Cluster, Cloud and Grid Computing, (2012).

[11] L. E. Bolton, L. Warlop and J. W. Alba, "Consumer Perceptions of Price (Un)Fairness", J. of Consumer Research, (2003).

[12] L. Xia, K. B. Monroe and J. L. Cox, "The Price Is Unfair! A Conceptual Framework of Price Fairness Perceptions", J. of Marketing, vol. 68, (2004).

[13] S. Lehmann and P. Buxmann, "Pricing Strategies of Software Vendors", Business and Information Systems Engineering, (2009).

[14] W. Wang, P. Zhang, T. Lan and V. Aggarwal, "Datacenter Net Profit Optimization with Individual Job Deadlines", Proc. Conference on Inform. Sciences and Systems, (2012).

[15] G. Moore, "Cramming More Components onto Integrated Circuits", Electronics, vol. 38, no. 8, (1965).

[16] M. Macias and J. Guitart, "A Genetic Model for Pricing in Cloud Computing Markets", Proc. 26th Symp. of Applied Computing, (2011).

[17] A. Osterwalder, "The Business Model Ontology - A Proposition in a Design Science Approach", Doctoral thesis, University of Lausanne, (2004).

[18] B. P. Rimal and E. Choi, "A Conceptual Approach for Taxonomical Spectrum of Cloud Computing”, Proc. 4th Int. Conference on Ubiquitous Inform. Technologies and Applicat., (2009).

[19] Q. Zhang, L. Cheng and R. Boutaba, "Cloud Computing: State-of-the-Art and Research Challenges", J. of Internet Services and Applicat, vol. 1, no. 1, (2010).

[20] M. Mihailescu and Y. M. Teo, "Dynamic Resource Pricing on Federated Clouds", Proc. 10th IEEE/ACM Int. Symp. on Cluster. Cloud and Grid Computing, (2010).

[21] C. S. Yeoa, S. Venugopalb, X. Chua and R. Buyyaa, "Autonomic Metered Pricing for a Utility Computing Service”, Future Generation Computer Syst., vol. 26, no. 8, (2010).

[22] J. Rohitratana and J. Altmann, "Impact of Pricing Schemes on a Market for Software-as-a-Service and Perpetual Software", Future Generation Computer Syst., vol. 28, no. 8, (2012).

[23] P. Nähring, "Value-Based Pricing", Bachelor Thesis, Linnaeus University, (2011).

[24] J. Jäätmaa, "Financial Aspects of Cloud Computing Business Models”, Inform. Syst. Sci., (2010).

[25] P. Samimi and A. Patel, "Review of Pricing Models for Grid and Cloud Computing", Proc. IEEE Symp. on Comp. and Informatics, (2011).

[26] Windows Azure, http://www.windowsazure.com/en-us/.

[27] H. Li, J. Liu and G. Tang, "A Pricing Algorithm for Cloud Computing Resources", Proc. Int. Conference on Network Computing and Inform. Security, (2011).

[28] Limelight Video Platform, http://www.limelightvideoplatform.com.

[29] A. Monaco, "A View inside the Cloud", http://theinstitute.ieee.org/technology-focus/technology-topic/aview-inside-the-cloud.

[30] S. Dutta, M. Zbaracki and M. Bergen, "Pricing Process as a Capability: A Resource-Based Perspective", Strategic Management Journal, vol. 27, no. 7, (2003).

[31] E. Iveroth, A. Westelius, C. Petri, N. Olve, M. Coster and F. Nilsson, "How to Differentiate by Price: Proposal for a Five-Dimensional Model”, European Management Journal, (2012).

[32] Google Compute Engine, https://cloud.google.com/products/compute-engine.

[33] J. Rohitratana and J. Altmann, "Agent-Based Simulations of the Software Market under Different Pricing Schemes for Software-as-a-Service and Perpetual Software", Economics of Grids, Clouds, Systems, and Services, ser. Lecture Notes in Computer Science, Altmann et al., Eds. Springer Berlin/Heidelberg (2010), pp. 6296.

[34] Amazon CloudFormation, http://aws.amazon.com/cloudformation.

[35] Rackspace Cloud, http://www.rackspace.com/cloud.

[36] Terremark, http://www.terremark.com.

[37] I. Agundez, Y. Penya and P. Bringas, “A Flexible Accounting Model for Cloud Computing”, Proc. Global Conference (SRII 11), IEEE Computer Society, Washington, DC, USA, (2011).

[38] Cloud Foundry, http://www.cloudfoundry.com.

[39] Heroku, http://www.heroku.com.

[40] R. Piro, A. Guarise and A. Werbrouck, "An Economy-Based Accounting Infrastructure for the Datagrid", Proc. Int. Workshop on Grid Computing (GRID 03), (2003).

[41] Windows Azure Compute, http://www.windowsazure.com/en-us/home/features/cloud-services. 
International Journal of Grid and Distributed Computing

Vol.6, No.5 (2013)

[42] Force, http://www.force.com.

[43] Google Apps, http://www.google.com/intl/en/enterprise/apps.

[44] Microsoft Office 365, http://www.microsoft.com/en-my/office365/online-software.aspx.

[45] Innkeypos, http://www.youtube.com/user/InnkeyPOS.

[46] Quickbooks Online, http://quickbooksonline.intuit.com. 